\title{
Utopia no fim do homem soviético
}

\section{Ercio do Carmo Sena Cardoso}

Doutor; Pontifícia Universidade Católica de Minas Gerais, Belo Horizonte, MG, Brasil erciosena@gmail.com

\section{José Milton Santos}

Mestre; Pontifícia Universidade Católica de Minas Gerais, Belo Horizonte, MG, Brasil jmilton@pucminas.br

\section{Resumo}

A proposta deste estudo é de uma análise da utopia na obra $O$ fim do homem soviético. No artigo, são apresentadas distintas recomendações sobre o livro da escritora e jornalista Svetlana Aleksiévich, relacionando-o, principalmente, com aspectos do jornalismo literário. Escrito a partir de relatos e depoimentos de pessoas comuns, o trabalho da autora é analisado por meio de falas cotidianas que abordam o fim do socialismo na União Soviética. A autora busca a percepção da grande narrativa sobre a construção socialista na visão das pessoas ordinárias, afetadas diretamente por esse período. Seis categorias de análise são definidas e excertos da obra, considerados mais representativos, são destacados na análise dos autores.

\section{Palavras-chave}

Fim do socialismo. Utopia. Relatos comuns. Jornalismo literário.

\section{0 coral de narrativas}

"Todos nós somos filhos do socialismo." (BONET, 2015, doc. não paginado). A afirmação, feita em recente entrevista ao Le Monde - reproduzida na versão nacional do El País -, é da escritora e jornalista Svetlana Aleksiévich, nascida na Ucrânia em 1948 e ganhadora do prêmio Nobel de Literatura em 2015. A Academia Sueca justificou a premiação por "[...] seus escritos polifônicos, um monumento ao sofrimento e à coragem nos nossos tempos". (BONET, 2015, doc. não paginado). Em seu último livro, O fim do homem 
soviético, retratou a vida de pessoas comuns representativas da população da ex-URSS. Juntamente com os livros anteriores A Guerra não tem rosto de mulher, Vozes de Tchernóbil, As últimas testemunhas e Os rapazes de zinco, compõe o quinteto sobre a Grande utopia comunista. No Brasil, apenas os três primeiros títulos foram publicados. Além do Nobel, a autora foi agraciada com premiações internacionais como o Erich Maria Remarque Peace Prize, em 2001, e o National Book Critics Circle Award, em 2006. O fim do homem soviético recebeu o Prêmio Médicis Ensaio, em 2013, e foi considerado o Melhor Livro do Ano pela revista Lire.

Para os opositores de qualquer forma de socialismo, o relato de Svetlana é também um meio singular de trazer o testemunho sobre a desilusão de homens e mulheres que viram na experiência socialista uma grande tragédia. A Porto Editora (2015), primeira a publicar o livro em português, o apresenta como uma prova necessária a “[...] manter viva a memória da tragédia da URSS e narrar a pequena história que está por trás de uma grande utopia." (PORTO EDITORA, 2015, doc. não paginado). A obra, no entanto, não é só isso. Assim como o coral de vozes constitui o relato polifônico do fim de um tempo, as visões e as opiniões acerca desse período não são únicas e, menos ainda, definitivas.

A Academia Sueca creditou a Svetlana a invenção de um novo gênero literário “[...] 'uma história de emoções' - uma 'colagem de vozes humanas de cuidadosa composição', as quais foram registradas em entrevistas." (FIGES, 2016, doc. não paginado). As narrativas são apresentadas como histórias orais, refletindo mais a experiências dos depoentes do que os acontecimentos históricos, embora eles estejam entrelaçados aos sentidos que sustentam a narração dos entrevistados. A pluralidade de memórias recobre os sentidos do texto, sendo transformada em literatura. Embora a prática da história oral não tenha sido tão difundida na URSS quanto no ocidente, o trabalho de Svetlana Aleksiévich foi influenciado pelas primeiras tentativas de se fazer esse tipo de relato na União Soviética. 0 escritor russo Alés Adamóvitch exerceu considerável influência sobre a autora com o trabalho de narrar experiências dos combatentes nos anos de 1940. Essas narrativas foram contraponto a outras que exaltavam o mito da história oficial soviética.

Adamovitch exerceu grande influência sobre Aleksiévitch, que a ele se refere como seu mentor. Suas técnicas, no entanto, diferem. Se o primeiro intercala comentários ao longo das entrevistas, Aleksiévitch jamais interrompe os entrevistados. Quando começou a trabalhar, no início da década de 80, essa prática, tivesse a jornalista consciência disso ou não, já se tornara padrão na história oral no Ocidente - ensinava-se que toda 
interrupção não apenas influenciava, mas também contaminava a narrativa do entrevistado. (FIGES, 2016, doc. não paginado).

A escolha de Aleksiévich foi se aproximar do próprio contexto que viveu na infância, valorizando as pequenas histórias contatas nos vilarejos sobre a epopeia da Segunda Guerra Mundial. Apesar dos relatos de vidas comuns, trata-se de um grande panorama sobre o desmonte do império soviético constituído por entrevistas e conversas gravadas entre 1991 e 2012. As entrevistas procuraram refletir pessoas que, assim como Aleksiévich, viveram a maior parte de suas vidas sob o sistema soviético. Essas pessoas, segundo a própria autora, tiveram muita dificuldade em reconstruir sua própria identidade depois do fim do regime.

Como exilados no território de um país desaparecido, falam de uma nova Rússia que lhes parece estranha. Por utilizar técnicas da história oral, a autora é cobrada por não explicitar o histórico de cada entrevistado ou mesmo o local de cada entrevista e os diferentes contextos em que elas se deram, dada a diferença de dez anos que separam as primeiras narrativas das últimas. Na polifonia da obra de Aleksiévich, diversos discursos, soviéticos e pós-soviéticos, se manifestam sobre as transformações das sociedades que compunham o império, provocadas pela política de abertura do governo Gorbatchev, agindo no cotidiano e nas concepções ideológicas até então hegemônicas. A polifonia, segundo Bakhtin e Bezerra (2002), significa a essa multiplicidade de vozes controversas que se manifestam explicitamente no interior do texto. Essas múltiplas vozes são independentes, mas formam uma combinatória. Todos os textos são dialógicos e explicitam tensões e conflitos de muitas falas sociais.

O livro O fim do homem soviético reflete a vida de pessoas, afetadas por transformações, que se tornam personagens dessa história sobre o sentimento de perda com a derrocada da sociedade socialista e as perspectivas de outro modelo de vida. No entanto, a autora não escreve sobre política diretamente. "Não faço perguntas sobre o socialismo, mas sobre o amor, o ciúme, a infância, a velhice. Sobre música, dança, penteados. Sobre milhares de detalhes de uma vida que vai desaparecendo." (ALEKSIÉVICH, 2016, p. 24).

A oralidade ilustra o largo espectro de questões suscitadas pela mudança: guinada ideológica, feridas por cicatrizar, idiossincrasias da alma russa, atrito geracional, revolução nos costumes, novos oligarcas, Putin e o capitalismo selvagem dos anos 2000, nostalgia do passado. Gorbachev paga por quase tudo. Subtítulo exacto: Um Tempo de Desencanto. (PITTA, 2015, doc. não paginado) 
A história parece revelar um romance coletivo. A autoria é o criterioso trabalho de articulação de falas comuns que, do seu lugar, protagonizaram os grandes acontecimentos que levaram ao fim a tentativa de criar um novo ser humano, fruto e condição da experiência socialista. A criação do Novo Homem, como era costume dizer, foi meta constante do regime em suas várias fases para a formação de um único povo, o povo soviético. Apesar do título do livro, a autora considera que o homo sovieticus continua vivo.

Em alguns momentos, a frustação pela expectativa de mudança leva os interlocutores da autora a odiarem a si mesmos por terem aceitado mudar. A vergonha de retornar ao capitalismo, a nostalgia dos valores socialistas e da estabilidade material se fundem na transição entre os tempos para formar a nova configuração política e ideológica.

Ao responder à pergunta do jornal El País sobre os motivos pelos quais Aleksiévich deve ser lida, Ricard San Vicent (2015), tradutor e editor de Svetlana na Espanha, diz que o trabalho da autora "É uma boa combinação entre jornalismo e literatura." (SAN VICENT, 2015, doc. não paginado). Acrescenta, ainda que o prêmio Nobel a ela concedido se deve a um reconhecimento de seu trabalho documental, onde "[...] acaba o trabalho jornalístico e começa o literário." (SAN VICENT, 2015, doc. não paginado). Sem pretensão de classificar o fazer da autora, cabe destacar algumas características da obra que podem ser reconhecidas no gênero jornalismo literário.

A reportagem literária ou, para usarmos um termo mais amplo, o jornalismo literário vai além da notícia e mesmo da reportagem comum pela imersão [...] profunda no conhecimento do objeto reportado através de pesquisa com técnicas como a observação participante, entrevistas em profundidade, exame de documentos e testemunhos de terceiros e, quando possível, convivência com as pessoas envolvidas no acontecimento. Portanto, não se prende apenas à apuração dos fatos, mas utiliza outras fontes disponíveis, como fazem os historiadores. (SANTOS, 2016, p. 47).

Esse trabalho minucioso possibilita a construção de uma narrativa inconsútil, preenchendo as lacunas com interpolações possibilitadas pelo conjunto das informações colhidas. Portanto, na estratégia da construção textual, esse jornalismo utiliza recursos da literatura tais como descrição detalhada das cenas, figuras de linguagem como metáforas, metonímias, sinédoque e ironia, dentre outras, e uma pontuação rítmica que prende a atenção do leitor. Nesse ponto, as estratégias textuais de Svetlana Aleksiévich trazem algumas diferenças. Não obstante, mesmo não se utilizando desses recursos estilísticos 
comuns ao jornalismo literário, a autora consegue formatar um texto narrativo e marcadamente reflexivo.

Sodré (2012) afirma que o jornalismo literário é capaz de produzir esse tipo de narrativa densa, reflexiva e que, na sua apreensão da factualidade, tem grande capacidade de aprofundar o conhecimento do mundo presente. É mimético na concepção aristotélica de apreender da realidade aspectos que possibilitam a construção de um discurso semelhante ou homólogo a ela, e não simples imitação.

\begin{abstract}
Usar recursos consagrados na literatura para melhor realizar uma reportagem ou uma notícia não implica produzir ficção literária. Na realidade, outras práticas textuais descritivas do real-histórico valiam-se, mais ou menos nessa mesma época, de recursos ficcionais. (SODRÉ, 2012, p. 157).
\end{abstract}

Esse autor relembra que, mesmo nos tradicionais relatos de viagens, o que prevalecia não era a precisão objetiva dos fatos, mas os modos de representar de maneira densa a experiência humana vivida. Esses "modos" podem emergir como recursos estilísticos de reportagens reflexivas de elaboração mais demorada. Isso acontece quando a preocupação quantitativista, que considera que há mais conhecimento com mais dados e detalhes do acontecimento, é substituída pela dimensão sensível, tema que já havia tratado em seu livro Estratégias Sensíveis.

Em seguida, Sodré versa sobre o delineamento de um novo intelectual, sem a pretensão clássica de representar o saber universal, capaz de articular o saber técnico com a crítica, que pode ser observado em relevo no trabalho de Svetlana Aleksiévich. "A unidade intelectual informação/cultura se poria, assim, a serviço da escuta das vozes silenciadas na história e da compreensão do Outro, isto é, da diversidade simbólica." (SODRÉ, 2005, p. 117). 0 que haveria de essencialmente crítico não é a racionalidade argumentativa, mas o que emerge de sensível nas vozes até então silenciadas.

O jornalismo literário rompe com os padrões do chamado jornalismo objetivo, pois não se prende aos fatos e acontecimentos da atualidade. Ele incorpora recursos da literatura e não se prende à produção de um texto impessoal, mas, pelo contrário, incorpora a subjetividade. (SANTOS, 2016, p. 52-53).

0 repórter foge do texto padronizado e "[...] presta muito mais atenção do que o jornalismo tradicional ao uso da oralidade, ou seja, à forma com que as pessoas expressam 
seus pensamentos, sentimentos e suas ações, enfim, sua forma de ver e de se relacionar com o mundo." (MARTINEZ, 2009, p. 72).

0 trabalho do repórter tem como diferencial essa imersão na realidade, no que está à sua frente, no momento mesmo do acontecimento. A função de sua profissão é produzir narrativas para transmitir às outras pessoas o que viu, ouviu e sentiu. Para Edvaldo Pereira Lima:

O ideário do Jornalismo Literário Avançado prima, assim, por um desejo de abandono de qualquer leitura preconceituosa do real. Em lugar de se ater exclusivamente a um viés racionalista de compreensão, procura aquilatar as situações e acontecimentos em pauta sob um modo de entendimento que começa a partir dos seus personagens. Aliás, para essa modalidade narrativa de não ficção não existem fontes, mas sim personagens. As pessoas são personagens da vida real. (LIMA, 2013, p. 74).

A obra analisada se posiciona na luta pela disputa de sentidos, colocando-se no campo da contra-hegemônica, entendendo-se hegemonia na concepção gramsciana como direção cultural, política e moral da sociedade pelo bloco histórico no poder. Resgata um pensamento crítico que lhe distancia de uma perspectiva de prometer uma utopia irrealizável, aproximando-a de uma crítica do tempo presente marcado por narrativas de sujeitos ordinários. Em síntese, o jornalismo literário perfaz o gesto que, partindo da imediaticidade intrínseca à atividade, alcança determinada permanência, aprofundando nossa compreensão sobre seres humanos e o mundo presente (SANTOS, 2016).

Nesse sentido, a obra de Svetlana Aleksiévich apresenta-se como uma alternativa a representações hegemônicas, sendo mais um labor a refletir a utopia como crítica da realidade social. A partir das experiências relatadas pela autora, até então produzidas como ausentes, emergem conhecimentos, caminhos e formas de lidar com práticas cotidianas que, se não fossem narradas, estariam condenadas ao esquecimento. 0 que se advoga no trabalho da autora é a defrontação com uma realidade inóspita, porém com grande potencial para emergência de utopias realistas. Assim, nos convém resgatar esse sentido de utopia presente na história para confrontá-los com as narrativas de um desencanto proposta por Aleksiévich. 


\section{A utopia}

Uma das distinções que Boaventura Santos (2017) faz do tempo presente com o tempo passado diz respeito à relação entre experiência e expectativa. 0 autor explica que, nas sociedades antigas, a experiência definia as expectativas: quem nascia em uma família de pobres viveria pobre, e o mesmo se observava em uma família de iletrados. No tempo presente, embora as delimitações entre classes e cultura existam, é possível transitar de um lugar para outro. No momento em que as experiências e expectativas para a grande maioria da população mundial são negativas, abrem-se também caminhos para se pensar em utopias realistas.

A palavra utopia foi recuperada do grego por Thomas More, escritor inglês, para designar o país imaginário chamado Utopia - $(u)$ é a partícula negativa e (topus), lugar. "Utopia literalmente significa não-lugar, não país, não região. Mas, ainda assim, um lugar imaginável, um estado de ser, um modelo a conquistar." (NEOTTI, 1973, p. 3). Projeto literário e político de More (2001), A utopia, publicada em 1516, tem sido apresentada como uma contundente crítica às instituições dominantes do século XVI. Pode se dizer que a utopia tem sido um estímulo dinamizador da história do mundo ocidental.

A história de um estado de perfeição imaginário contrasta com a experiência do mundo vivido na Inglaterra de Thomas More. A proposta do autor serviu para destacar as assimetrias desse tempo ao criar um mundo de intuições que beiraram a perfeição. Como resultado de um projeto literário, essas representações imaginadas estabeleceram a crítica social por meio de um romance. Deprecia as leis de sua época e investe contra as medidas instituídas para punir desviantes. "O roubo não merece a morte, e não há castigo suficientemente horrível para impedir que roube quem não tem outra maneira de prover à sua carência mais extrema: a fome." (MORE, 2001, p. 27). O texto revela um autor pertencente a uma tradição humanista, considerado santo pela Igreja Católica e homenageado como um dos precursores do socialismo marxista na antiga União Soviética.

Após releituras e derivações obra de More, a palavra utopia adquiriu variações que permitem lhe identificar duas grandes significações. Na primeira acepção, é definida como um "projeto de natureza irrealizável; quimera, fantasia" (HOUAISS, 2002, p. 1914), que levou o próprio Marx a combater o propósito dos socialistas denominados utópicos, para os quais, o socialismo seria alcançado de forma gradativa. Para atingir esse propósito, no entanto, não haveria um caminho, uma luta de classes e uma necessária mudança na dinâmica da vida 
social, o que levou Marx a formular uma posição contrária ao socialismo utópico, definida por ele como socialismo científico. 0 engano dos socialistas utópicos era acreditar que a força persuasiva de suas ideias poderia influenciar e convencer a burguesia. Prometiam um futuro paradisíaco sem considerar as condições que a realidade impunha a essas transformações.

Entretanto, se tomarmos outro significado da palavra utopia, podemos defini-la em uma segunda acepção como "[...] qualquer descrição imaginativa de uma sociedade ideal, fundamentada em leis justas e em instituições político-econômicas verdadeiramente comprometidas com o bem-estar da coletividade [...]" (HOUAISS, 2002). Por essa segunda definição, não estaríamos necessariamente diante de um projeto infactível. Podemos também tomar o sentido de utopia como "[...] um conjunto de possibilidades materiais das sociedades futuras, de tal modo que todas as decisões e escolhas presentes ficam subordinadas a estas construções utópicas." (SEPÚLVEDA, 1962, p. 66). Assim, a força da utopia está menos na idealização de um futuro e mais na crítica do que se manifesta no tempo presente.

Embora o debate teórico tenha oposto socialistas utópicos e Marx como representante do socialismo científico, a obra de More e o modo de vida dos utopianos foram, ao seu modo e ao seu tempo, inspiradores das experiências socialistas ulteriores, inclusive o chamado socialismo científico que serviu como referência ao modelo de sociedade construída a partir da Revolução Russa de 1917. Na sociedade imaginada por More, os utopianos praticam um sistema que tende à igualdade dos bens sociais. A produção reunida é utilizada de acordo com a medida que cada um considera necessária para satisfazer suas precisões. "Para que pensar que alguém peça mais do que precisava, se não receia que nada lhe falte? De fato, o que torna os animais de todas as espécies ambiciosos e rapaces é o medo de privações futuras." (MORE, 2001, p. 64). Se construir um novo ser humano era um projeto da sociedade soviética na rejeição ao capitalismo, a obra de More também pode ser caracterizada como um confronto do incipiente mundo moderno que nascia na Europa, com aspectos capitais do humanismo renascentista. As questões trazidas por ele apontam para o sentido da utilização dos bens, a desimportante acumulação de riquezas, as questões sociais e políticas, bem como a reflexão ética e filosófica de seu tempo.

Portanto, ao se utilizar do termo utopia para se analisar a representação desse termo no texto de Svetlana Aleksiévich, escolhemos tratá-lo de acordo com a segunda acepção apresentada. Abordaremos a expressão cunhada para designar uma sociedade ideal, 
construída na tradição humanista onde as leis e as instituições a ser erigidas visem o bemestar coletivo, tal qual assinala o mundo do espelho do avesso proposto por More, refletindo criticamente a sociedade inglesa do século XVI.

Boaventura de Sousa Santos (2007), ao buscar alternativas de sociabilidades no presente, trabalha com o conceito de "razão indolente". Para ele, essa é uma razão preguiçosa, que não se exercita o suficiente para perceber e conhecer outras realidades num mundo marcado por vasta diversidade epistemológica. As categorias predominantes nas formas de produzir conhecimento são redutoras na medida em que desconhecem experiências locais, que são desperdiçadas, porque acontecem em lugares remotos. Em função disso, não são legitimadas pelas ciências hegemônicas. Na realidade, são desacreditadas, desencorajadas e, às vezes, invisibilizadas, produzidas como não existentes.

Esse modo de razão indolente, que chamo razão metonímica, faz algo que, a meu ver, é um dos dois aspectos do desperdício da experiência: contrai, diminui, subtrai o presente. Ou seja, temos uma concepção do presente que é contraída, precisamente porque a concepção da racionalidade que possuímos não nos permite ter uma visão ampla do nosso presente. (SANTOS, 2007, p. 26).

A escolha de identificar a utopia como crítica da realidade abre possiblidades de novos sentidos trazidos pela experiência literária que valoriza narrativas comuns sobre o fim de uma era. Afinal, essas experiências se misturam no imaginário e nas representações da espécie homo soviéticus, desfigurada desde o fim do século passado, em crise e em busca de novas representações. Como essas representações não estiveram ligadas apenas ao contexto soviético, mas também inspiraram movimentos anticoloniais, antimperialistas e até anticapitalistas no mundo inteiro, é importante que um novo olhar sobre essas experiências, emergentes na base social desse sistema, nos defronte com sentidos de novas utopias. A crise pode nos interpelar para construir esperanças, assim como os sintomas de uma doença a se oferecer como um alerta de cura ao corpo social. No presente momento, Santos (2017) nos chama atenção para os perigos de ditaduras que se apresentam com faixada democrática e multipartidarismo, mas efetivamente têm contribuído para esvaziar o conteúdo democrático. Destaca o predomínio de sociedades politicamente democráticas, porém socialmente fascistas. Na síntese proposta pelo autor, o fim do século XX é marcado por uma fatalidade. "Chegamos ao início do século XXI e não temos a revolução, nem temos uma democracia capaz de se defender dos antidemocratas." (SANTOS, 2017, p. 17). 0 
trabalho que acessamos nos coloca diante do desafio de conhecer uma realidade antes de agir para transformá-la. Para demonstrar que existem outras realidades fora da que se conhece, Boaventura Santos propõe combater a razão metonímica, que toma o todo pela parte, se utilizando do que ele define como Sociologia das Ausências. Esse conceito pretende mostrar que muito do que não existe em nossa sociedade é produzido como não-existente. 0 autor aponta formas que sustentam essa razão metonímica, indisposta a conhecer novas realidades:

[...] o inferior, o local ou particular, e o improdutivo. Tudo o que tem essa designação não é uma alternativa crível às práticas científicas avançadas, superior, globais, universais, produtivas. Essa ideia de que não são críveis gera o que chamo a subtração do presente, porque deixa de fora, como não-existente, invisível, "descredibilizada", muita experiência social. (SANTOS, 2007, p. 32).

A partir dessa síntese, Santos propõe inverter a situação dada pela Sociologia das Ausências pela Sociologia das Emergências. Nesse sentido, as monoculturas dos saberes e práticas seriam substituídas por ecologias, fazendo com que experiências ausentes se tornem presentes. Nosso diálogo com o trabalho de Svetlana Aleksiévich, estimulado pelo gesto da autora em revelar falas de um cotidiano que emergem na reportagem ou na literatura, ocorre sob a mesma inspiração desse olhar, sob uma insurgência de narrativas que não abandonaram a utopia.

Assim, o trabalho da jornalista, ao exibir vozes comuns, nos possibilita encontrar novas realidades expandidas no testemunho de pessoas que viveram, conheceram e se dispuseram, a seu modo, a realizar a grande experiência socialista no mundo. Em seguida, algumas categorias, construídas a partir da leitura, serão destacadas, buscando evidenciar aspectos panorâmicos do texto. A escolha delas pretende colocar em relevo pequenos excertos, considerados pelos autores deste texto como as narrativas mais representativas da obra de Svetlana Aleksiévich.

\section{A cozinha como lugar da crítica social}

Espaço de subversão, lugar de falas proibidas, nas cozinhas reside o lugar predileto da crítica ao estado soviético. A pequena desconfortável cozinha, parte da chamada Khruschoba, nome jocoso dado aos apartamentos construídos nas periferias das grandes 
cidades no planejamento soviético. A construção dos anos 1960, época do governo Khruschév, foi combinada num trocadilho entre o nome do líder soviético e a palavra truschoba, algo que se aproxima da palavra favela em português.

A cozinha russa... A pequena e miserável cozinha da 'Khruschoba' de nove a doze metros quadrados (com sorte), com um banheiro atrás de uma parede fininha. [...] A cozinha para nós não é apenas um lugar para preparar as refeições; é também sala de jantar, sala de estar, escritório, tribuna. Um lugar para sessões coletivas de psicoterapia. No século XIX, toda cultura russa vivia em propriedades senhoriais, mas no século XX, nas cozinhas. (ALEKSIÉVICH, 2016, p. 35).

As cozinhas representaram o lugar de liberdade possível onde se podia exercer, no espaço de confiança, entre amigos e família, a crítica ao sistema soviético e às formas de poder exercidas. Nesse espaço, a insegurança era combatida com a troça, o riso. Os assuntos mais delicados e passíveis de repressão eram interpostos com interrupções simuladas, como se estivessem se referindo a um terceiro interlocutor, ausente no compartilhamento do espaço, mas presente como um vigia oculto, um pan-óptico. Pelos relatos, pode se inferir que as cozinhas eram representações atomizadas de grande dissidência ao regime, erigida de maneira oculta, sem controle ou vigilância oficial, mas representativa na base social. A cozinha tornou-se o lugar de ressignificação do cotidiano experimentado na União Soviética. Aqueles que estavam na produção também faziam história não apenas reproduzindo culturas e rituais que mantinham o regime, mas subvertendo as relações com ele no espaço privado. 0 relato sobre o cotidiano da vida privada, em particular no papel destacado das cozinhas, contribuiu para explicar o funcionamento do sistema. "[...] o cotidiano e o estudo da vida privada são, essencialmente, uma maneira de abordar a história econômica e social." (PRIORE, 1997, p. 265).

As práticas aí narradas mostram uma população cindida entre os sujeitos que se apresentavam com uma dupla personalidade. No espaço público, em concordância com as políticas do regime e, na cozinha, espaço onde esse mesmo sujeito manifestava sua inconformidade e se colocava abertamente contra a realidade que vivia. Cotidiano e história não eram noções contraditórias nesses relatos. 0 olhar sobre ambos permitiu elucidar melhor os laços entre história, cultura, sociedade e implicações individuais. No vão do espaço constituído entre esses vários duplos, o regime se esfacelava e perdia o apoio, sem ter sido socorrido por seus defensores mediante seu desmoronamento. 


\section{Carrascos e vítimas}

Em um dos depoimentos, surge uma questão sobre o porquê de Stálin não ter sido julgado. Segundo Aleksiévich (2016), a própria interlocutora responde a sua pergunta, concluindo retoricamente que havia milhões de "Stálins" por toda União Soviética. Relata a história do seu pai que ficou preso por 10 anos e quando voltou, ainda assim, queria viver depois de presenciar horrores de violência e morte.

Quem denunciou o meu pai foi o nosso vizinho... tio Iura... Por uma bobagem, como dizia a minha mãe. Eu tinha sete anos. 0 tio Iura levava os filhinhos para pescar, me levava também, para andar a cavalo. Consertava a nossa cerca. Entendeu? O retrato do carrasco é totalmente diferente: é uma pessoa comum, até mesmo boa... Normal... (ALEKSIÉVICH, 2016, p. 53.)

0 acesso aos arquivos na época do governo Iéltsin permitiu que várias famílias conhecessem denunciantes e as histórias que os envolveram. O estado policial esteve representado em todas as localidades com várias pessoas cumprindo o papel de vigilância, dispostas a contribuir com o cerco e o controle. As ramificações desse estado encontraram nas pessoas um jeito de participar da repressão sem se incomodar com o papel que desempenharam. "Onde é que você viu uma pessoa honrada na época do Stálin?" (ALEKSIÉVICH, 2016, p. 54.), indaga Ólia, a mulher que responde à pergunta de uma entrevistada que teve seu tio denunciado por ela, justificando os motivos de sua colaboração com o Estado Policial.

\section{A carteirinha do partido}

Era uma honra ser chamada para trabalhar no Partido, uma experiência incomum, irrecusável! As aulas de russo e literatura foram trocadas para que a personagem retratada fosse a terceira secretária do Partido. A função era tão prestigiada que valia a pena se produzir e celebrar a rara oportunidade, motivo de orgulho para toda a família. A crença no Partido sobreviveu a esse período e ainda permanece, a ponto de ela não se desfazer da carteirinha do Partido, independente do que venha a acontecer. 
Se eu acreditava no comunismo? Digo com sinceridade, não vou mentir: eu acreditava na possibilidade de um sistema justo de vida. Até hoje... como eu já disse... eu acredito. Estou cansada de ficar ouvindo essas histórias de como vivíamos mal durante o socialismo. Tenho orgulho da época soviética! Ninguém tinha uma vida elegante, mas tinha uma vida normal. Tinha amor e amizade... vestidos e sapatos... As pessoas ouviam com gosto os escritores e os artistas, mas agora pararam com isso. (ALEKSIÉVICH, 2016, p. 75).

A personagem defende seu ponto de vista justificado como uma tentativa de criar uma civilização alternativa. No lamento, ressente-se pela ausência de trabalhadores comuns no governo e na imprensa. A restauração do capitalismo os transformou em personagens invisíveis na nova realidade. As críticas feitas à alta burocracia sobre condições especiais e privilégios foram generalizadas como se fizessem parte da prática de todos os membros do Partido.

No novo regime, os vencedores não são guerreiros, mas os ricos que se mantêm afastados do povo e se isolam em suas mansões. A indignação pela ostentação da riqueza, celebrada na tevê e em outros meios de comunicação, são agravadas quando a intelligentsia russa parece servir unicamente ao dinheiro. Na nova Rússia, somente os padres falam das coisas da alma, as pessoas comuns deixaram de fazê-lo. Os partidários da perestroika que abriram caminho para o capitalismo não justificam suas atitudes. No passado, a carteirinha do Partido tinha uma considerável simbologia. Nem todo soviético estava à altura de sua posse. Os que a possuíam eram reverenciados. Resignada, a antiga militante indaga: “Estamos avançando, rumo à vitória do capitalismo. Não é isso?” (ALEKSIÉVICH, 2016, p. 79).

\section{0 malogro da promessa}

Até agosto de 1991, nós vivíamos em um país, depois de agosto, em outro. Antes de agosto, o meu país se chamava URSS... Quem sou eu? Sou um daqueles idiotas que defenderam o Iéltsin. Estive na Casa Branca, disposto a ficar deitado na frente de um tanque. As pessoas saíram às ruas como numa onda, num ímpeto. Mas elas estavam dispostas a morrer pela liberdade, não pelo capitalismo. (ALEKSIÉVICH , 2016, p. 176). 
Outra faceta dos depoimentos é o engano. 0 fracasso da promessa de liberdade pela qual a maioria do povo soviético ansiava depois de tantos anos de sujeição. Nas bandeiras pelas quais lutaram, em nenhum momento se reivindicou o retorno ao capitalismo. 0 significado da luta pela liberdade nos anos 1990 resultou em outras formas de sujeição. Agora, não mais à máfia do Krémlin, mas aos capitalistas do ocidente.

O novo lugar alcançado não foi o da independência ideal, tão somente um conjunto de direitos em face da autoridade política do Estado. Ao contrário do que se podia esperar como resultados daquelas jornadas, ainda se encontram coagidos ante a força constrangedora de outra moral. Uma nova disposição de espírito, indiferente à dor do outro, admiradora do lucro e de valores que envergonhavam a espécie do homo soviéticus. Sem disposição para enfrentar as circunstâncias adversas, os antigos socialistas que lutaram por liberdade veem os valores coletivos que fundaram aquela sociedade ruírem, deixando no lugar apenas constrangimento e queixa pela perda da antiga identidade. 0 poder soviético, longe de ser ideal, é visto por muitos que viveram as duas experiências como um domínio mais digno. Apesar dos privilégios de uns tantos, não havia ninguém excessivamente rico, nem pobreza extrema. A filosofia que se alastra como pólvora na Rússia de hoje é o contrário do humanismo. Não se valoriza o ser humano, a cultura e o potencial da condição humana, o respeito ao outro. Os novos interesses que se cultuam são os do mercado. Os velhos socialistas são criticados por se apegarem a valores que não são mais estimados na tevê e nos lugares públicos.

\section{0 futuro não é mais como era antigamente}

$\mathrm{Na}$ análise sobre as pessoas de seu tempo, Thomas More se queixava da estreiteza de espírito de algumas pessoas que não sabiam lidar com a crítica ou o gracejo. Além desse tipo, incluía no rol de seus desprazeres os que não suportavam a alegria e o divertimento. Na apresentação de seu trabalho, suas apreciações procuravam se prevenir da incapacidade dos que não conseguissem julgá-lo e contemplá-lo criticamente. “A grande maioria dos homens é ignorante e muitos desprezam a sabedoria. Os que são rudes e bárbaros só aceitam o que, à sua semelhança, se apresenta bárbaro e rude." (MORE, 2001, p. 16). Apoiado sobre os dilemas de seu tempo, sua atividade se colocou como um exame 
minucioso dos valores e da ideologia que fundavam as relações sociais na modernidade emergente. Era o valor do futuro de um "não lugar" que se almejava no exame dos princípios de uma época.

Em dezembro de 2011, uma grande manifestação na Rússia com mais de cem mil pessoas parecia ser o espectro de outra revolução rondando o país, segundo um depoente. Entretanto, ao temer o destino de suas impressões, indagou a autora: Pelo que se luta nesse tempo? “O que escolheram dessa vez?” (ALEKSIÉVICH, 2016, p. 382).

Há cento e vinte anos, Dostoiévski terminou Os irmãos Karamázov. Lá ele escreveu sobre os eternos 'meninos russos', que sempre discutem 'sobre as questões universais, e nada mais: se Deus existe, se existe a imortalidade. Dentre os que não acreditam em Deus, mas que ficam falando de socialismo e de anarquismo, da reconstrução de toda a humanidade de acordo com um novo modelo, a mesmíssima coisa aparece, as mesmas questões, só vistas pelo outro lado'. (ALEKSIÉVICH, 2016, p. 382).

Apesar dos movimentos na praça, o observador receia os seus resultados. Não reconhece nos movimentos, nem nas pessoas, a alma de um povo, os meninos russos admirados por Dostoiévski. Dos movimentos à dispersão, nada a recolher, juntar, dar continuidade, unificar ou evoluir para uma situação melhor. Se uma revolução pode ser algo arriscado, porque não se sabe onde ela vai dar, não se pode deixar que as coisas sejam decididas sem participação coletiva. Na pluralidade de motivações, não há um só sentido entre tantos apelos que reúnem novas multidões diante do Kremlin. A euforia das revoluções acaba depressa e as pessoas são mais reticentes em apostar no seu formato tradicional. A nova era e suas urgências pedem experiências mais suaves, transparentes. Ao mesmo tempo em que as pessoas se empenham nas movimentações, hesitam diante do uso que seus atos podem ter. Temem os saqueadores e, além deles, que diferentes tipos de oportunismos embalem o vigor de suas ações em nome da democracia, dos direitos e da liberdade.

\section{0 confronto: comunistas $x$ mercado}

Até meus quatorze anos nós levamos uma vida tranquila. Até a perestroika... Vivemos normalmente, até começar o capitalismo, aí na televisão começaram a falar do 'mercado'. Ninguém entendia muito bem o 
que era isso, e ninguém explicou nada. Mas tudo começou com o fato de que virou moda xingar o Lênin e o Stálin. Os jovens xingavam, os mais velhos ficaram quietos, eles saíam do trólebus se ouviam alguém xingando os comunistas. Na nossa escola, o jovem professor de matemática era contra os comunistas, mas o velho professor de história era a favor dos comunistas. Em casa, a vovó dizia: 'No lugar dos comunistas, agora vai ter agiotas'. A minha mãe discutia com ela: dizia que não, que seria uma vida bela e justa; ela ia às manifestações, quase engasgava de empolgação quando recontava para nós os discursos do Iéltsin. Era impossível convencer nossa avó: 'Trocaram o socialismo por bananas. Por chicletes....' (ALEKSIÉVICH , 2016, p. 409).

Entre revolucionário e criminoso, a figura de Iéltsin, embora tenha tido o apoio da maioria, dividiu opiniões. Apesar de incorporar novos hábitos, muitas pessoas mais velhas ainda se vinculavam aos valores soviéticos, cultivados ao longo de toda vida. As memórias constituíam uma narrativa gloriosa de feitos históricos, de vitórias importantes, com destaque para a derrota do nazismo. Ter participado de uma forma ou de outra dessa condição era motivo de orgulho na história pessoal de cada um. Em três gerações, o interesse pela política foi decrescendo. Os mais velhos foram os que mais se apegaram aos valores comunistas e viram com mais desconfiança os movimentos no final dos anos 1980 e ao longo dos anos de 1990. Não acreditaram nas promessas de mudança. Pressentiam que o resultado das reformas, da perestroika, da liderança de Iéltsin levaria o grande país a um retrocesso. A segunda geração, em geral das mesmas famílias, representou o confronto com os velhos comunistas, enquanto os mais jovens, netos da primeira geração, puderam testemunhar o litígio entre as duas concepções e foram eles que vieram a experimentar de fato a vida no retorno ao capitalismo e ao mercado. A experiência, fruto desses embates, da presença viva entre os valores do mercado e o comunismo, traz uma nova abrangência, uma nova sabedoria e deixa a desconfiança como melhor perícia adquirida na vivência desses testemunhos.

Nos relatos da experiência de retorno ao capitalismo, muitas vítimas ficaram pelo caminho. 0 mercado logo se impôs como medida de todos os serviços e necessidades. É evidente que essa nova regra abalou convicções de quem apostou tudo na liberdade do comércio. As relações agora tinham outros parâmetros, outras medidas. Na Rússia de hoje, é possível encontrar em gerações mais jovens o retorno de ícones dos tempos de seus bisavós. Não se sabe em que proporção ou em que medida isso será significativo, mas a inconformidade com o tempo da prometida liberdade e dos valores do mercado também criou resistências, recusas e crítica. 


\section{Onde ficaram indistintos vermelhos e brancos}

O que posso lembrar? Vivo como todo mundo. Teve a perestroika... 0 Gorbatchev... A carteira abriu a cancela: "Você ouviu, não tem mais comunistas." "Como não?" "Fecharam o Partido." Ninguém atirou, nada. Agora dizem que foi uma grande potência e perdemos tudo. Mas o que foi que eu perdi? (ALEKSIÉVICH, 2016, p. 593).

No último depoimento, as observações de uma cidadã, que vive a mais de mil quilômetros de Moscou, indicam a indiferença entre os regimes socialista e capitalista em seu cotidiano. Relata uma vida de trabalho intenso, com referências sobre os líderes de seu país, de suas histórias, de suas narrativas heroicas, mas não consegue relacionar todas essas transformações com sua própria vida. Se a União Soviética foi ou não uma grande potência, isso não importa. 0 cotidiano seguiu sem grandes transformações, vivendo em uma casa “[...] sem água, sem esgoto, sem gás [...] Para nós, brancos e vermelhos são a mesma coisa." (ALEKSIÉVICH, 2016, p. 593594). Numa vida de sucessões de tempos, parece que sempre se viveu da mesma forma. 0 trabalho duro e honesto, os hábitos simples e a vida austera são marcas de um depoimento indiferente aos poderes que se revezaram. A neve, os regimes e as rotinas se sucedem nas diferentes estações do ano. É sabido que aconteceram protestos, manifestações, mas nada mudou para os habitantes daquele lugar acostumados a plantar batatas e esperar a primavera.

Depois de tantos cruzamentos do cotidiano com acontecimentos políticos, a autora finaliza o livro com um breve depoimento, focalizando um lugar distante onde essas mudanças fizeram pouca diferença. Essas duas páginas não são a síntese de outras quase seiscentas que articularam grandes transformações e o dia-a-dia que forjou e abalou a espécie homus soviéticus, mas serviu para apontar que, na grandeza das mutações sociais, uma vida comum seguiu indiferente a tudo. 0 registro final da narrativa não parece estar ali por sua representatividade, mas talvez por ser fiel à maior crítica à revolução e aquilo que ela pretendeu criar, uma espécie de ser humano imbuída de um objetivo e poucas diferenciações. Havia ali mesmo, no território soviético, lugares onde essas mudanças se fizeram presentes apenas como narrativas distantes, embora tenham significado muito na 
vida de um povo e do planeta. Nos rincões mais longínquos da Rússia, nem mesmo pode ter se formado a espécie homo soviéticus. Nos testemunhos recolhidos no antigo território da grande nação, esse tipo peculiar não demonstrou seu fim e, apesar do que o título do livro sugeriu, afirmou sua permanência na emergência dos relatos sobre o amor, o ciúme, a infância, a velhice e o cotidiano.

\section{Referências}

ALEKSIÉVICH, Svetlana. 0 fim do homem soviético. São Paulo: Companhia das Letras, 2016.

BAKHTIN, Mikhail; BEZERRA, Paulo. Problemas da poética de Dostoiévski. 3. ed. Rio de Janeiro: Forense Universitária, 2002.

BONET, Pilar. Bielorussa Svetlana Alexievich ganha prêmio Nobel de Literatura 2015. El País, Minsk, 8 out. 2015. Cultura.

FIGES, Orlando. A nova história de Svetlana Aleksiévitch. Piauí, São Paulo, n. 122, nov. 2016

HOUAISS, Antônio. Dicionário Houaiss. Rio de Janeiro: Objetiva, 2002.

LIMA, Edvaldo Pereira. Memória do futuro: Jornalismo Literário Avançado no século XXI.

Revista Brasileira de Inovação Científica em Comunicação, São Paulo, v. 5, n. 2, p. 68-78, 2013.

MARTINEZ, Mônica. Jornalismo literário: a realidade de forma autoral e humanizada. Estudos em Jornalismo e Mídia, Florianópolis, v. 6, n. 1, p. 71-83, jan./jun. 2009.

MORE, Thomas. A utopia. São Paulo: Martin Claret, 2001.

NEOTTI, Clarêncio. Tempo e utopia. Revista de Cultura Vozes, Rio de Janeiro, v. 67, n. 1, p. 3 -4, jan./fev. 1973.

PITTA, Eduardo. Crítica: o fim do homem soviético. Sábado, Lisboa, 4 jun. 2015.

PORTO EDITORA. 0 fim do homem soviético. Porto: Porto Editora, 2015. Notícias.

PRIORE, Mary Del. História do cotidiano e da vida privada. In: CARDOSO, Ciro Flamarion; VAINFAS, Ronaldo. Domínios da História: ensaios de teoria e metodologia. Rio de Janeiro: Campus, 1997.

SAN VICENT, Ricard. Por que você precisa ler Svetlana Aleksiévitch, a nova Nobel de literatura? El País Brasil, São Paulo, 8 out. 2015. Folha Cultura.

SANTOS, Boaventura Souza. Renovar a teoria crítica e reinventar a emancipação social. São Paulo: Boitempo, 2007. 
SANTOS, Boaventura Sousa. Democracia em tempos incertos. 2017. Transcrição da palestra realizada na Pontifícia Universidade Católica de Minas Gerais, Belo Horizonte, em 27 abr. 2017.

SANTOS, José Milton. A estética no jornalismo literário: estudo de reportagens brasileiras contemporâneas. 2016. Dissertação (Mestrado em Comunicação Social) - Pontifícia Universidade Católica de Minas Gerais, Belo Horizonte, 2016.

SEPÚLVEDA, Carlos. Escola, Utopia e Hipermoralidade. Revista Tempo Brasileiro, Rio de Janeiro, v.1, n. 1, p. 61-68, jan./mar. 1962.

SODRÉ, Muniz. A narração do fato: notas para uma teoria do acontecimento. Petrópolis: Vozes, 2012.

\title{
Utopia at the end of the Soviet man
}

\begin{abstract}
The proposal of this study is an analysis of the utopia in the book The end of the Soviet man. In the article, different recommendations on the book of the writer and journalist Svetlana Aleksiévich are presented, relating it mainly to aspects of literary journalism. Written from reports and testimonies of ordinary people, the author's work is analyzed through everyday speeches that address the end of socialism in the Soviet Union. The author seeks the perception of the great narrative about socialist construction in the view of ordinary people, directly affected by that period. Six categories of analysis are defined and excerpts from the book, considered more representative, are highlighted in the authors' analysis.
\end{abstract}

\section{Keywords}

End of socialism. Utopia. Common reports. Literary journalism.

Recebido em 24/11/2017

Aceito em 07/05/2018 